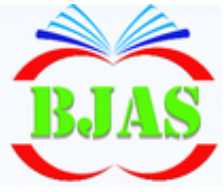

ISSN 1814 - 5868
Available online at http://bjas.bajas.edu.iq

https://doi.org/10.37077/25200860.2020.33.2.05

College of Agriculture, University of Basrah
Basrah Journal

of Agricultural

Sciences

E-ISSN: 2520-0860

\title{
Effect of Natural and Synthetic Sources of Lycopene on Productive Performance, Carcass Quality and viscera relative weights of Japanese Quail Coturnx japonica Temminck \& Schlegel, 1849
}

\author{
Issa A.T. Al-Jrrah ${ }^{1 *} \&$ Rabia J. Abbas ${ }^{2}$ \\ ${ }^{1}$ Ministry of Agriculture, Directorate of Basrah Agriculture, Iraq \\ ${ }^{2}$ Department of Animal Production, College of Agriculture, University of Basrah, Iraq \\ *Corresponding author: assa_1969@yahoo.com
}

Received 12 April 2020; Accepted 14 July 2020; Available online 26 September 2020

\begin{abstract}
This study aimed to investigate the effect of natural and synthetic sources of lycopene on performance, carcass quality and organ morphology of Japanese quail. A total of 420 one-day-old quail chicks were randomly distributed among seven treatments. First treatments were fed a basal diet as a control. Second and third treatments were fed diet supplemented with tomato fruit (Lycopersicon esculentum) powder (TOM) (17 and $34 \mathrm{~g}^{\mathrm{kg}}$ 1 equal to 50 and $100 \mathrm{mg} \cdot \mathrm{kg}^{-1}$ lycopene), fourth and fifth treatments were fed diet supplemented with red bell pepper (Capsicum annum L.) fruit powder (RBP) (16.23, 32.46 g.kg ${ }^{-1}$ equal to 50 and $100 \mathrm{mg} . \mathrm{kg}^{-1}$ lycopene), sixth and seventh treatments were fed diet supplemented with 50 and $100 \mathrm{mg} \cdot \mathrm{kg}^{-1}$ pure lycopene powder (LY), respectively. Results indicated that final body weight and weight gain were improved significantly in comparison to control and T3. Feed efficiency was improved compared to control, T3 and T7. Production and economic efficiency index significantly better than control. A significant elevation $(\mathrm{P} \leq 0.05)$ in relative weight of thigh, small intestine, duodenum, cecum weight and length for T3 treatment, T7 in jejunum and ileum weight, T4 in carcass weight and gizzard, T5 in the liver compared to control. The relative weight of abdominal fat, spleen, bursa and bursa index were decreased $(\mathrm{P} \leq 0.05)$ in supplemented treatments in comparison to control. In conclusion, natural sources of LY (50 mg. $\left.\mathrm{kg}^{-1}\right)$ either TOM (17 g.kg $\left.{ }^{-1}\right)$ or RBP (16.23 g. $\left.\mathrm{kg}^{-1}\right)$, could be used to improve performance, production and economical efficiency index, carcass traits and some gut measurements of quails.
\end{abstract}

Keywords: Tomato, Red bell pepper, lycopene, Performance, Carcass quality, Quail.

\section{Introduction}

Plants and their biological active chemical constituents, present numerous opportunities for the improvement of livestock production by inclusion in the diet (Wallace et al., 2010). In the human diet, fruits and vegetables are the most important phytochemical compounds. A diet rich in fruits and vegetables is well established for its effectiveness in promoting human health, especially regulating body weight (Estruch et al., 2013; Mozaffarian, 2016), On the other hand, the presence of 


\section{Al-Jrrah \& Abbas / Basrah J. Agric. Sci., 33(2): 52-66, 2020}

lycopene in tomato increasing the importance of consuming it locally and in the entire world, as well as its high nutritional value (Aziz et al., 2019).

Besides that, the presence of phytochemicals in Capsicum pepper makes them not only useful and much cheaper alternative to synthetic drugs but the phytochemicals can be harnessed as crude drugs for the production of novel drugs (Mercy \& David, 2018).

Natural plant supplements with diets of poultry can be used to enhance antioxidant defense mechanisms and reduce the intensity of oxidation processes, which negatively affect the quality of poultry products (Ognik et al. 2016). In this regard. Tawfeek et al. (2014) conducted that the use of antioxidant compounds in the feeding of broilers can improve immune function and reduce deleterious effects of reactive oxygen species (ROS) on cells. Lycopene is a carotenoid present in vegetables and ripe fruit and has been proved to be the most potent antioxidant among various common carotenoids (Sun et al, 2015). Lycopene is mainly found in tomatoes and other red fruits and vegetables (Mendelová et $a l ., 2013)$, on the other hand, tomatoes and their products are major sources of lycopene in food (Arain et al., 2018). According to Abdullah et al. (2019), the Jordanian vine tomato dried waste has a substantial amount of lycopene with twice oxidative scavenging power of that of ascorbic acid.

Palozza et al. (2012) reported that lycopene scavenges ability was twice than $\alpha$ - tocopherol and ten times higher than $\beta$-carotene. The previous study has focused on carotenoids, which are fat-soluble antioxidants found in peppers due to their antioxidant properties (Rao
\& Rao, 2007) and such as their provitamin A activity, antioxidant action, immune modulation and involvement in cell signaling (Tundis et al., 2011). Additionally, lycopene has activated antioxidant enzymes and nuclear transcription factor systems in heat-stressed broilers (Sahin et al., 2016). Several studies reported healthpromoting and antioxidant potentials of lycopene natural sources. In this regard; Sahin et al. (2008) revealed that lycopene-rich tomato powder significantly improved feed consumption, body weight gain and decreased concentration of malondialdehyde (MDA) in muscles, liver and serum of Japanese quail reared under heat stress.

Selim et al. (2013) reported that dietary inclusion of lycopene-enriched tomato byproducts at a level of $1 \%$ in broilers feed under heat stress enhanced total antioxidant capacity and lowered MDA level. Recently, Mezbani et al. (2019) reported that lycopene (100 mg. $\left.\mathrm{kg}^{-1}\right)$ improved performance and antioxidant status of broilers. On the other hand, a study on Novogen white laying hens shows that diet supplemented with ground linseed (4.5\%), dried tomato pastes (1\%) and sweet pepper powder (1\%) mix increased the Roche yolk colour fan score and redness of egg yolk colour (Omri et al., 2019). Therefore, the objective of this study was to determine the effect of lycopene from natural and synthetic sources on the performance of Japanese quail birds.

\section{Material \& Methods}

\section{Experimental birds and treatments}

The experiment was conducted in Quail Farm, Department of Animal Production, College of Agriculture, University of Basrah during the period from $19 / 3 / 2018$ to $7 / 5 / 2018$. A total of 


\section{Al-Jrrah \& Abbas / Basrah J. Agric. Sci., 33(2): 52-66, 2020}

420 one-day-old of Japanese quail was randomly allocated to seven treatments, three replicates and 20 birds per replicate according to the Completely Randomized Design. All chicks reared in cages (replicates) with dimensions $(60 \times 70 \times 60) \mathrm{cm}$. The chicks were allowed free access to feed and water and fed the basal diet formulated to meet the nutrient requirements of quail. The following seven dietary treatments were prepared by adding various levels of dried tomato fruit (Lycopersicon esculentum) powder (TOM) and red bell pepper fruit (Capsicum аппиит L.) powder (RBP) to the basal diet as a source of natural lycopene, the content of which was previously estimated from lycopene (Table 2). Experimental diets were designed as follows: First treatment were fed a basal diet (BD) as a control. Second and third treatments were fed diet supplemented with tomato fruit (Lycopersicon esculentum) powder (TOM) (17 and $34 \mathrm{mg} . \mathrm{kg}-1$ equal to 50 and $100 \mathrm{mg} . \mathrm{kg}-1$ lycopene, respectively). Fourth and fifth treatments were fed diet supplemented with red bell pepper (Capsicum annum L.) fruit powder (RBP) $\left(16.23,32.46\right.$ g.kg $^{-1}$ equal to 50 and 100 mg.kg-1 lycopene. The sixth and seventh treatments were fed diet supplemented with 50 and $100 \mathrm{mg} \cdot \mathrm{kg}^{-1}$ pure lycopene powder (LY), respectively.

The fruits of tomato and red sweet pepper used in this study were provided by local Liveability percentage $=100$ - mortality percentage producers. Fruits of both tomato and red peppers were dried in the shade, ground into a fine powder using an electric dry mill, and then powders were stored in black plastic bags at room temperature $\left(25^{\circ} \mathrm{C}\right)$. With the beginning of the experiment, fruit powder was added to the basal diet at various levels. Lycopene pure powder used in this experiment was purchased from (Shaanxi Jintai Biological Engineering Company-China). The ingredients and chemical composition of the basal diet were shown in table (1). Chemical analysis of TOM and RBP fruit powder was carried out according to AOAC (2016). The amount of lycopene was estimated according to the method of Markovic et al. (2006) (Table 2). The chicks were fed a starter diet until 21 days of age, followed by a grower diet from 22 to 49 days. All chicks were kept under uniform management conditions throughout the experiment period of 49 days. Live body weight (LBW) was determined through the period of a starter and finisher. Feed intake (FI) was recorded for the corresponding periods and feed efficiency ratio (FCR) was calculated. Production Index (PI) was calculated according to the equation of Naji (2006):

Production index (PI)

$=\frac{\text { Average of live weight in }(\mathrm{gm}) \times \text { liveability percentag }}{\text { Age in days } \times \mathrm{FCR} \times 10}$

The economic efficiency index (EEI) was calculated according to Naji (2006):

Economic efficiency index $(\mathrm{EEI})=\frac{\text { Average of live weight in }(\mathrm{kg}) \times \text { liveability percentage } \times 100}{\text { Age in days } \times \text { FCR }}$ 
Al-Jrrah \& Abbas / Basrah J. Agric. Sci., 33(2): 52-66, 2020

Table (1): Ingredients and nutrient composition of quail starter and grower diets.

\begin{tabular}{|c|c|c|}
\hline Ingredient $(\%)$ & Starter diet 1-21 day & Grower diet 22-49 day \\
\hline Yellow corn & 50.00 & 56.00 \\
\hline Wheat & 8.50 & 8.50 \\
\hline Soybean meal $(44 \%)$ & 33.00 & 28.00 \\
\hline${ }^{1}$ protein concentrates $(44 \%)$ & 6.00 & 5.00 \\
\hline Vegetable oil & 1.00 & 1.00 \\
\hline Dicalcium phosphate & 0.25 & 0.25 \\
\hline Limestone & 0.75 & 0.75 \\
\hline${ }^{2}$ Mineral premix & 0.25 & 0.25 \\
\hline Sodium chloride & 0.25 & 0.25 \\
\hline Total & 100 & 100 \\
\hline \multicolumn{3}{|l|}{ Calculated composition ${ }^{3}$} \\
\hline Metabolizable energy $\left(\mathrm{kcal} \mathrm{kg}^{-1}\right)$ & 2934 & 2995 \\
\hline Crude protein $(\%)$ & 22.60 & 20.47 \\
\hline Crude fat $(\%)$ & 3.10 & 3.08 \\
\hline Crude fibre $(\%)$ & 3.61 & 3.53 \\
\hline Calcium $(\%)$ & 0.74 & 0.68 \\
\hline Phosphorus available $(\%)$ & 0.35 & 0.32 \\
\hline Lysine $(\%)$ & 1.16 & 1.07 \\
\hline Methionine $(\%)$ & 0.42 & 0.39 \\
\hline Methionine + Cysteine (\%) & 0.77 & 0.73 \\
\hline Calorie: protein ratio & 129.82 & 146.31 \\
\hline
\end{tabular}

${ }^{1}$ Protein concentrate used from Al-Hayat Company, Jordanian Origin, to provide the following per kg of diet: $44 \%$ protein, $2800 \mathrm{kcal} . \mathrm{kg}^{-1} \mathrm{ME}, 12 \%$ fat, $25 \%$ ash, $5 \%$ calcium, $2.9 \%$ phosphorus, $2.55 \%$ methionine + Cysteine, $2.8 \%$ lysine.$^{2}$ Content $/ \mathrm{kg}$ : Manganese $80 \mathrm{~g}$; iron $80 \mathrm{~g}$; zinc $50 \mathrm{~g}$; copper $10 \mathrm{~g}$; cobalt $2 \mathrm{~g}$; Iodine $1 \mathrm{~g}$; excipient q.s - 1,000 g. ${ }^{3}$ Was calculated according to the chemical composition of feedstuff contained in NRC (1994).

Table (2): Proximate analysis and lycopene content of tomato and red bell pepper Fruits (\% on a dry weight basis).

\begin{tabular}{|l|c|c|}
\hline Component $(\%)$ & $\begin{array}{c}\text { Tomato } \\
\text { powder }\end{array}$ & Red bell pepper \\
\hline Dry matter & 85.08 & 91.52 \\
\hline Crude protein & 14.53 & 13.13 \\
\hline Crude fat & 3.71 & 11.47 \\
\hline Ash content & 8.36 & 6.72 \\
\hline Crude fibre & 10.60 & 23.90 \\
\hline Available carbohydrate & 62.80 & 44.78 \\
\hline Organic matter & 91.64 & 93.28 \\
\hline Metabolized energy $\left(\mathrm{Kcal}_{\mathrm{N}} \mathrm{kg}^{-1}\right)^{*}$ & 2793.86 & 2729.04 \\
\hline Lycopene $\left(\mathrm{mg} .100 \mathrm{~g}^{-1}\right)$ & 293.58 & 307.99 \\
\hline
\end{tabular}

* ME was calculated according to Lodhi et al. (1976). 


\section{Al-Jrrah \& Abbas / Basrah J. Agric. Sci., 33(2): 52-66, 2020}

\section{Carcass and internal weights evaluation}

At the end of the seventh-weeks experiment, three birds of similar body weight from each treatment group were used to study slaughter traits. The birds were randomly selected, individually weighed and slaughtered. Different internal organs were collected, weighed and expressed as a percentage of the live body weights. Weight of liver, heart, gizzard, spleen, bursa of fabricius, abdominal fat, small intestine, duodenum, Jejunum and ileum were measured. The length of the gastrointestinal tract consists of small intestinal, duodenum, jejunum, ileum and the cecum was also measured and recorded and expressed as a percentage of the live body weights. The relative weights of carcasses cut (breast and thigh) were expressed as a percentage of carcass weight. Dressing percentage was calculated according to the equation of AlFayadh et al. (2011):

Dressing percentage $=\frac{\text { Dressed weight }(\mathrm{gm})}{\text { Live weight }(\mathrm{gm})} \times 100$

Bursa index was calculated by dividing the weight of bursa of fabricius gland for each treatment group by the weight of the gland for the control group (Lucio \& Hitchner, 1979).

\section{Statistical analysis}

All data were subjected to a one-way ANOVA procedure by using SPSS program software (2012) significant treatment means were separated by using the Least Significant Difference (L.S.D.) test at $\mathrm{P} \leq 0.05$.

\section{Results \& Discussion}

\section{Production performance}

The effect of dietary supplementation with tomato fruit powders (TOM), the red bell pepper fruit powders (RBP) and pure lycopene (LY) on the productive performance of quail chicks are presented in table (3). The result revealed that the experimental treatments supplemented with TOM (17 g. $\left.\mathrm{kg}^{-1}\right)$ RBP and LY, that final body weight and total weight gain were improved significantly $(\mathrm{P} \leq 0.05)$ in comparison to control and T3. The feed conversion ratio was improved $(\mathrm{P} \leq 0.05)$ as compared to control, T3, and T7, meanwhile all supplemented treatments did not affect the total feed intake. The improvement in final body weight, total weight gains and cumulative feed conversion ratio (in $\mathrm{T} 2, \mathrm{~T} 4, \mathrm{~T} 5$ and $\mathrm{T} 6$ ) for supplementary treatments may be due to presences of lycopene in additive materials and its role as a strong antioxidant in reducing oxidative stress and protecting cells from free radicals that lead to oxidation of saturated fatty acids and damage to the cell membrane (Rao \& Agarwal, 1999). It is well known that rapid growth rates and improve feed conversion lead to high oxidative stress in birds and that lycopene plays an important role in strengthening the body's antioxidant defense system ( Ševčíková et al., 2008; Khan et al., 2014). Moreover, lycopene is a powerful antioxidant that able to reduce the harmful effects of free radicals and prevent oxidation of fat, proteins and nucleic acids, and that the improvement in productive traits may be related to its antioxidant properties (Wang, 2012). Also, the improvement in growth performance (body weight and weight gain) may have been linked to its antioxidant feature (Rao \& 
Al-Jrrah \& Abbas / Basrah J. Agric. Sci., 33(2): 52-66, 2020

Table (3): Effect of dietary tomato, red bell pepper fruits powder and lycopene on the overall (1-7 wks.) performance Japanese quail.

\begin{tabular}{|c|c|c|c|c|c|c|c|c|}
\hline \multirow{2}{*}{ Parameters } & \multicolumn{7}{|c|}{ Dietary treatments } & \multirow[b]{2}{*}{ Sig. } \\
\hline & $\mathrm{T} 1$ & $\mathrm{~T} 2$ & T3 & $\mathrm{T} 4$ & T5 & T6 & T7 & \\
\hline $\begin{array}{l}\text { Initial live } \\
\text { weight }(\mathrm{g})\end{array}$ & $\begin{array}{c}26.71 \pm \\
0.21\end{array}$ & $\begin{array}{c}27.07 \pm \\
0.38\end{array}$ & $\begin{array}{c}27.63 \pm \\
0.27\end{array}$ & $\begin{array}{c}28.30 \pm \\
0.96\end{array}$ & $\begin{array}{c}27.03 \pm \\
1.04\end{array}$ & $\begin{array}{c}27.77 \pm \\
0.50\end{array}$ & $\begin{array}{c}27.07 \pm \\
0.94\end{array}$ & NS \\
\hline $\begin{array}{l}\text { Final body } \\
\text { weight (g) }\end{array}$ & $\begin{array}{c}179.14^{\mathrm{d}} \pm \\
1.13\end{array}$ & $\begin{array}{c}192.89^{\mathrm{ab}} \pm \\
1.95\end{array}$ & $\begin{array}{c}184.27^{\mathrm{cd}_{ \pm}} \\
0.44\end{array}$ & $\begin{array}{c}191.03^{b} \\
2.99\end{array}$ & $\begin{array}{c}196.82^{\mathrm{a}} \pm \\
0.90\end{array}$ & $\begin{array}{c}193.20^{\mathrm{ab}} \pm \\
0.69\end{array}$ & $\begin{array}{c}188.15^{\mathrm{bc}} \pm \\
2.50\end{array}$ & $*$ \\
\hline $\begin{array}{l}\text { Body } \\
\text { weight } \\
\text { gain (g) }\end{array}$ & $\begin{array}{c}152.44^{\mathrm{d}_{ \pm}} \\
0.92\end{array}$ & $\begin{array}{c}165.83^{\mathrm{ab}_{ \pm}} \\
1.99\end{array}$ & $\begin{array}{c}156.64^{\mathrm{cd}} \pm \\
0.22\end{array}$ & $\begin{array}{c}162.73^{\mathrm{b}} \pm \\
3.02\end{array}$ & $\begin{array}{c}169.79^{\mathrm{a}} \pm \\
1.94\end{array}$ & $\begin{array}{c}165.43^{\mathrm{ab}} \pm \\
1.19\end{array}$ & $\begin{array}{c}161.09^{b c} \pm \\
2.43\end{array}$ & $*$ \\
\hline $\begin{array}{l}\text { feed } \\
\text { intake, } \\
\mathrm{g} / \mathrm{bird}\end{array}$ & $\begin{array}{c}780.00 \pm \\
11.89\end{array}$ & $\begin{array}{c}747.72 \pm \\
16.45\end{array}$ & $\begin{array}{c}749.19 \pm \\
24.79\end{array}$ & $\begin{array}{c}763.51 \pm \\
32.39\end{array}$ & $\begin{array}{c}732.18 \pm \\
11.11\end{array}$ & $\begin{array}{c}756.75 \pm \\
33.20\end{array}$ & $\begin{array}{c}769.06 \pm \\
10.10\end{array}$ & NS \\
\hline $\begin{array}{l}\text { Feed } \\
\text { efficiency } \\
\left(\mathrm{g} \cdot \mathrm{g}^{-1}\right)\end{array}$ & $\begin{array}{c}4.354 \mathrm{a} \pm \\
0.087\end{array}$ & $\begin{array}{c}3.875 b c \pm \\
0.093\end{array}$ & $\begin{array}{c}4.064 \mathrm{abc} \pm \\
0.124\end{array}$ & $\begin{array}{c}3.996 b c \pm \\
0.171\end{array}$ & $\begin{array}{c}3.719 \mathrm{c} \pm \\
0.065\end{array}$ & $\begin{array}{c}3.914 b c \\
0.016\end{array}$ & $\begin{array}{c}4.086 \mathrm{ab} \pm \\
0.032\end{array}$ & $*$ \\
\hline $\begin{array}{l}\text { Production } \\
\text { index }\end{array}$ & $\begin{array}{c}8.47^{c_{ \pm}} \\
0.26\end{array}$ & $\begin{array}{c}10.16^{\mathrm{a}} \pm \\
0.30\end{array}$ & $\begin{array}{c}9.26^{\mathrm{b}} \pm \\
0.25\end{array}$ & $\begin{array}{c}9.78^{\mathrm{b}} \pm \\
0.40\end{array}$ & $\begin{array}{c}10.80^{\mathrm{a}} \pm \\
0.22\end{array}$ & $\begin{array}{c}10.09^{\mathrm{ab}} \pm \\
0.39\end{array}$ & $\begin{array}{c}9.26^{\mathrm{b}} \pm \\
0.05\end{array}$ & $*$ \\
\hline $\begin{array}{l}\text { Economic } \\
\text { efficiency } \\
\text { index }\end{array}$ & $\begin{array}{c}254.84^{\mathrm{a}} \pm \\
8.99\end{array}$ & $\begin{array}{c}174.18^{\mathrm{b}_{ \pm}} \\
7.87\end{array}$ & $\begin{array}{c}183.03^{b} \\
12.03\end{array}$ & $\begin{array}{c}183.65^{\mathrm{b}} \pm \\
15.71\end{array}$ & $\begin{array}{c}159.95^{\mathrm{b}} \pm \\
6.14\end{array}$ & $\begin{array}{c}178.68^{b_{ \pm}} \\
15.05\end{array}$ & $\begin{array}{c}188.44^{\mathrm{b}_{ \pm}} \\
3.04\end{array}$ & $*$ \\
\hline Mortality & 0.00 & 0.00 & 0.00 & 0.00 & 0.00 & 0.00 & 0.00 & NS \\
\hline
\end{tabular}

${ }^{a b c}$ Means in the same row with no common superscript are different significantly $(\mathrm{P} \leq 0.05)$. NS: None significant, $\mathrm{T} 1$ (control), T2 and T3 (Tomato fruits powder at the levels of 17 and $34 \mathrm{~g}^{\mathrm{kg}}{ }^{-1}$ in basal diet), T4 and T5 (Red bell pepper at the levels of 16.23 and $32.46 \mathrm{~g} . \mathrm{kg}^{-1}$ in basal diet) which was equivalent to 50 and $100 \mathrm{mg} \cdot \mathrm{kg}^{-1}$ lycopene respectively, T6 and T7 (lycopene powder at the levels of 50 and $100 \mathrm{mg} \cdot \mathrm{kg}^{-1}$ in basal diet) respectively.

Agarwal, 1999; Wang, 2012). Besides, the consumption of tomato and its species lead to improve digestion and increase absorption as a result of increased secretion and activity of the digestive system, this is due to palatability and its high content of antioxidants and nutrients (Zhao et al., 2011; Asadollahi et al., 2014). As well as, this improvement in growth performance may be due to the positive effect of lycopene on gut physiology in broiler chickens (Sun et al., 2015).

Shehata et al. (2018) confirmed that the addition of tomato pomace by $5 \%$ without enzymes to quail diets increased final weight of $29.36 \%$ as compared to control at 42 days of 


\section{Al-Jrrah \& Abbas / Basrah J. Agric. Sci., 33(2): 52-66, 2020}

age. The findings of the present study for body weight and body weight gain were in line with previous researches in broilers (Ali \& Al Massad, 2015; Sahin et al., 2016), quails (Shehata et al., 2018) and geese (Al-Janabi, 2015), who found a positive effect on growth performance when tomato and tomato residuals and lycopene used in poultry ration. On the other hand, in broilers, weight gain, feed intake and feed efficiency did not change significantly with the inclusion of 10 and $20\left(\mathrm{mg}_{\mathrm{kg}} \mathrm{kg}^{-1}\right)$ of lycopene or $17\left({\left.\mathrm{~g} . \mathrm{kg}^{-1}\right)}^{-}\right.$of tomato paste (which was equivalent to $5 \mathrm{ppm}$ of lycopene) in experiment lasted four weeks (Lee et al., 2016). In this respect, Marzoni et al. (2014) revealed that the inclusion of tomato skins extracts, which contained $200 \mathrm{mg}$ of lycopene per $\mathrm{kg}$ of diet did not affect the growth performance of broiler chickens. As well as, a study conducted by Dougnon et al. (2014) mentioned the supplementation of the diet with pepper (Capsicum frutescens) powder at 0.5 and $1 \%$ for one or two months had no noticeable effect on weight gain, feed consumption and feed conversion ratio of Hubbard broilers.

Regarding feed intake, our result supported the finding of the previous study, Sahin. et al. (2006) found no significant effect of lycopene on feed consumption of broiler chicks. The production index (PI) and economic efficiency index (EEI) are shown in table (2). The production index (PI) and economic efficiency index (EEI) are shown in table (2). Production and economic efficiency index significantly were better $(\mathrm{P} \leq 0.05)$ than control. Regarding for EEI, the results indicated that there was a significant decreased $(\mathrm{P} \leq 0.05)$ in EEI values of supplemented treatments as compared to control, which reflect the best economic efficiency value. The better feed conversion ratio in supplement treatments and the absences of mortality positively reflected on the improvement in PI and EEI. Also, the improvement in PI and EEI may be due to the presence of natural sources of lycopene from tomato powder, red bell pepper and synthetic lycopene in diets. The consequent increase of fats digestion and other nutrients resulted in exceeded body weight, weight gain, feed conversion ratio and low mortality rate (North, 1984).

Likewise, the improvement in the PI and EEI may be due to lycopene as a natural antioxidant that plays an important role inside and outside the cell in increasing utilization of nutrients, which is reflected on the improvement in productive performance of growing quail (Flint \& Garner, 2009). No quail chicks' deaths were observed throughout the experimental period. The effect of TOM, RBP and LY supplementation on carcass characteristics of quails aged 49 days are presented in table (4).

There was a significant difference $(\mathrm{P} \leq 0.05)$ in carcass weights, the relative weight of thigh, liver and gizzard. Birds fed on diets supplemented with (16.23 g. $\mathrm{kg}^{-1}$ ) RBP gave significantly $(\mathrm{P} \leq 0.05)$ the heaviest carcass weights compared to control and with TOM treated groups T2 and T3 (17 and 34 g. $\mathrm{kg}^{-1}$ ) respectively. These results are consistent with the increasing of growth rates which resulted in heavier slaughter weight, liver and gizzard. Birds fed on diets supplemented with (16.23 g. $\left.\mathrm{kg}^{-1}\right)$ RBP (T4) gave significantly $(\mathrm{P} \leq 0.05)$ the heaviest carcass weights compared to control and with TOM treated groups T2 and T3 (17 and 34 g. $\mathrm{kg}^{-1}$ ) respectively. These results are consistent with the increasing of 
Al-Jrrah \& Abbas / Basrah J. Agric. Sci., 33(2): 52-66, 2020

Table (4): Carcass characteristic at 49 days of the age of Japanese quail received tomato, red bell pepper fruits powder and lycopene in diets.

\begin{tabular}{|c|c|c|c|c|c|c|c|c|}
\hline \multirow{2}{*}{ Parameters } & \multicolumn{7}{|c|}{ Dietary treatments } & \multirow{2}{*}{ Sig } \\
\hline & T1 & $\mathrm{T} 2$ & T3 & $\mathrm{T} 4$ & T5 & T6 & $\mathrm{T} 7$ & \\
\hline \multirow{2}{*}{$\begin{array}{l}\text { Carcass } \\
\text { weight }(\mathrm{g})\end{array}$} & & & $113.88^{b} \pm$ & $139.12^{a} \pm$ & $\begin{array}{c}121.24^{\mathrm{ab}} \\
\pm\end{array}$ & $122.19^{\mathrm{ab}_{ \pm}}$ & $\begin{array}{c}127.28^{\mathrm{ab}} \\
\pm\end{array}$ & $*$ \\
\hline & 10.69 & 2.87 & 2.42 & 3.27 & 4.07 & 10.02 & 1.19 & \\
\hline \multirow{2}{*}{$\begin{array}{l}\text { Carcass } \\
\text { yield }(\%)\end{array}$} & $62.52 \pm$ & $67.83 \pm$ & $64.39 \pm$ & $72.43 \pm$ & $64.51 \pm$ & $64.98 \pm$ & $70.83 \pm$ & \multirow{2}{*}{ NS } \\
\hline & 5.02 & 6.13 & 5.41 & 1.27 & 1.38 & 4.40 & 4.01 & \\
\hline \multirow{2}{*}{$\begin{array}{l}\text { Breast yield } \\
(\%)\end{array}$} & $32.90 \pm$ & $29.28 \pm$ & $30.28 \pm$ & $32.29 \pm$ & $33.02 \pm$ & $34.65 \pm$ & $31.27 \pm$ & \multirow{2}{*}{ NS } \\
\hline & 3.32 & 2.74 & 2.10 & 1.55 & 1.42 & 1.01 & 0.16 & \\
\hline \multirow{2}{*}{$\begin{array}{l}\text { Thigh yield } \\
(\%)\end{array}$} & $10.98^{a b} \pm$ & $11.21^{\mathrm{ab}_{ \pm}}$ & $11.91^{\mathrm{a}} \pm$ & $11.45^{\mathrm{ab}_{ \pm}}$ & $11.82^{\mathrm{ab}_{ \pm}}$ & $10.75^{\mathrm{b}} \pm$ & $11.46^{\mathrm{ab}} \pm$ & \multirow{2}{*}{$*$} \\
\hline & 0.30 & 0.67 & 0.57 & 0.10 & 0.20 & 0.10 & 0.18 & \\
\hline \multirow{2}{*}{$\begin{array}{l}\text { Liver yield } \\
(\%)\end{array}$} & $1.81^{b_{ \pm}}$ & $2.68^{\mathrm{a}} \pm$ & $2.04^{\mathrm{ab}} \pm$ & $2.68 \mathrm{a} \pm$ & $2.98^{\mathrm{a}} \pm$ & $2.84^{\mathrm{a}_{ \pm}}$ & $2.45^{\mathrm{ab}_{ \pm}}$ & \multirow{2}{*}{$*$} \\
\hline & 0.3 & 0.42 & 0.46 & 0.207 & 0.34 & 0.49 & 0.62 & \\
\hline \multirow{2}{*}{$\begin{array}{l}\text { Heart yield } \\
(\%)\end{array}$} & $0.78 \pm$ & $0.92 \pm$ & $0.78 \pm$ & $0.98 \pm$ & $0.78 \pm$ & $0.88 \pm$ & $0.84 \pm$ & \multirow{2}{*}{ NS } \\
\hline & 0.11 & 0.09 & 0.09 & 0.06 & 0.03 & 0.09 & 0.07 & \\
\hline \multirow{2}{*}{$\begin{array}{l}\text { Gizzard } \\
\text { yield }(\%)\end{array}$} & $1.34^{b_{ \pm}}$ & $1.57^{\mathrm{ab}_{ \pm}}$ & $1.46^{\mathrm{ab}_{ \pm}}$ & $1.76^{\mathrm{a}_{ \pm}}$ & $1.54^{\mathrm{ab}_{ \pm}}$ & $1.51^{\mathrm{ab}_{ \pm}}$ & $1.76^{\mathrm{a}} \pm$ & \multirow{2}{*}{$*$} \\
\hline & 0.15 & 0.11 & 0.01 & 0.20 & 0.11 & 0.084 & 0.16 & \\
\hline
\end{tabular}

${ }^{a, b}$ Means in the same row with no common superscript are different significantly $(\mathrm{P} \leq 0.05)$. NS: None significant, $\mathrm{T} 1$ (control), T2 and T3 (Tomato fruits powder at the levels of 17 and $34 \mathrm{~g} \mathrm{~kg}^{-1}$ in basal diet), T4 and T5 (Red bell pepper at the levels of 16.23 and 32.46 g.kg ${ }^{-1}$ in basal diet) which was equivalent to 50 and $100 \mathrm{mg} \cdot \mathrm{kg}^{-1}$ lycopene respectively, T6 and T7 (lycopene powder at the levels of 50 and $100 \mathrm{mg} \cdot \mathrm{kg}^{-1}$ in basal diet) respectively.

growth rates which resulted in heavier slaughter weight. These results are consistent with the increasing of growth rates which resulted in heavier slaughter weight. The result showed a significant elevation $(\mathrm{P} \leq 0.05)$ in the relative weight of thigh for T3 treatment, T4 in carcass weight and gizzard, T5 in the liver as compared with control. The improvement in the carcass weight may be due to the improved in body weight (Table 3) and that there is a linear relationship between carcass weight and body weight (Al-Fayadh \& Naji, 1989), which positively reflect the weight of thighs, liver and gizzard.

Also, this improvement may be due to the role of lycopene in enhancing digestive enzyme activities, which increase the efficiency of 


\section{Al-Jrrah \& Abbas / Basrah J. Agric. Sci., 33(2): 52-66, 2020}

nutrients use, rapid growth and organs development, and body weight (Jang \& Moon, 2015). Similarly, with the present results, Leke et al. (2018) indicated that adding dry tomato powder to broiler diet by $12 \%$ led to an increase in carcass weight. On the contrary to our results; Lee et al. (2016) found no significant effect of lycopene at the levels of 10 or 20 mg. $\mathrm{kg}^{-1}$ or $17 \mathrm{~g} . \mathrm{kg}^{-1}$ of tomato paste which was equivalent to $5 \mathrm{ppm}$ of lycopene on relative Gastrointestinal traits (GIT) and internal organ of the experimental treatments in Japanese quail at 49 are shown in table (5). GIT relative weight and length, jejunum and ileum parts, small intestine and duodenum length were not differed respecting all treatments. There was a significant difference $(\mathrm{P} \leq 0.05)$ in relative weight and length of the small intestine, duodenum, jejunum, ileum parts, cecum and with the relative weight of abdominal fat, spleen, bursa of fabricius and bursa index.

Result showed a significant elevation $(\mathrm{P} \leq 0.05)$ in the relative weight of small intestine for T6 treatment, T3 in duodenum, T7 in jejunum and ileum as compared with control. As regards to cecum weight and length, quails in $\mathrm{T} 3$ gave significantly $(\mathrm{P} \leq 0.05)$ the highest rates as compared with control. Abdominal fat, spleen, bursa of fabricius relative weight and bursa index were declined in all dietary groups in comparison with the control one, except T6 in spleen and T2 and T3 in the bursa of fabricius, which equal to control. The decline in the relative weight of spleen and bursa of fabricius recorded in the current study was positive evidence of animal health. This evidence indicates that the sources of lycopene in experimental treatments contributed to improving the immunity of birds, which reflected positively on the absence of birds' mortality. The most important mechanism of lycopene to preserve animal health is enhancing the immunity system by preventing the synthesis of cytokines or mineral correlated proteins responsible for inflammation (Vitale et al., 2010).

This evidence indicates that the sources of lycopene in experimental treatments (TOM, RBP and LY) contributed to improving the immunity of birds, which reflected positively on the absence of birds' mortality. The most important mechanism of lycopene to preserve animal health is enhancing the immunity system by preventing the synthesis of cytokines or mineral correlated proteins responsible for inflammation (Vitale et al., 2010).

Our results coincided with the finding of ElTazi (2014) who showed the lowest percentage of abdominal fat and the highest percentages of liver and gizzard due to the consumption of mixture diet ratio of red and black peppers at $1 \%$ in comparison with the control. Also, Ševčíková et al. (2008) showed the broiler chickens fed 50-100 mg lycopene. $\mathrm{kg}^{-1}$ feed, the lycopene treatments achieved the lowest fat percentage in breast cuts. On other hands, AlShammary (2017) reported that the supplementation of zinc and lycopene at a level of 30 and $200 \mathrm{mg} \cdot \mathrm{kg}^{-1}$ in quail diet respectively, resulted in a significant improved in carcass yield, liver and breast weight, gastrointestinal tract and small intestine lengths, histological characteristics of the duodenum and reduced abdominal fat at the age of 42 days. 
Al-Jrrah \& Abbas / Basrah J. Agric. Sci., 33(2): 52-66, 2020

Table (5): Effects of different levels of tomato, red bell pepper fruits and lycopene powder in diets on some gastrointestinal traits and internal organ in Japanese quail at 49 days of age.

\begin{tabular}{|c|c|c|c|c|c|c|c|c|}
\hline \multirow[t]{2}{*}{ Parameters (\%) } & \multicolumn{7}{|c|}{ Dietary treatments } & \multirow[t]{2}{*}{ Sig } \\
\hline & $\mathrm{T} 1$ & $\mathrm{~T} 2$ & $\mathrm{~T} 3$ & $\mathrm{~T} 4$ & $\mathrm{~T} 5$ & T6 & $\mathrm{T} 7$ & \\
\hline $\begin{array}{l}\text { Gastrointestinal } \\
\text { tract weight } \%\end{array}$ & $\begin{array}{c}4.12 \pm \\
0.51\end{array}$ & $\begin{array}{l}4.40 \pm \\
0.63\end{array}$ & $\begin{array}{r}4.96 \pm \\
1.01\end{array}$ & $\begin{array}{c}3.87 \pm \\
0.31\end{array}$ & $\begin{array}{l}3.68 \pm \\
0.27\end{array}$ & $\begin{array}{c}3.78 \pm \\
0.19\end{array}$ & $\begin{array}{l}4.62 \pm \\
0.16\end{array}$ & NS \\
\hline $\begin{array}{l}\text { Gastrointestinal } \\
\text { tract length }(\%)\end{array}$ & $\begin{array}{c}64.33 \pm \\
6.84\end{array}$ & $\begin{array}{c}63.00 \pm \\
6.80\end{array}$ & $\begin{array}{c}55.33 \pm \\
1.45\end{array}$ & $\begin{array}{c}68.00 \pm \\
5.77\end{array}$ & $\begin{array}{c}66.33 \pm \\
6.84\end{array}$ & $\begin{array}{c}61.33 \pm \\
4.33\end{array}$ & $\begin{array}{c}60.00 \pm \\
1.15\end{array}$ & NS \\
\hline $\begin{array}{l}\text { Small intestine } \\
\text { weight }(\%)\end{array}$ & $\begin{array}{c}1.31^{\mathrm{b}_{ \pm}} \\
0.08\end{array}$ & $\begin{array}{c}2.25^{\mathrm{ab}} \pm \\
0.08\end{array}$ & $\begin{array}{c}2.60^{\mathrm{a}} \pm \\
0.52\end{array}$ & $\begin{array}{c}2.19^{\mathrm{ab}_{ \pm}} \\
0.38\end{array}$ & $\begin{array}{c}2.30^{\mathrm{ab}} \pm \\
0.36\end{array}$ & $\begin{array}{c}2.63^{\mathrm{a}_{ \pm}} \\
0.43\end{array}$ & $\begin{array}{c}2.85^{\mathrm{a}_{ \pm}} \\
0.47\end{array}$ & $*$ \\
\hline $\begin{array}{l}\text { Small intestine } \\
\text { length }(\%)\end{array}$ & $\begin{array}{c}22.84 \pm \\
3.28\end{array}$ & $\begin{array}{c}22.92 \pm \\
0.79\end{array}$ & $\begin{array}{c}22.22 \pm \\
1.88\end{array}$ & $\begin{array}{c}21.89 \pm \\
2.39\end{array}$ & $\begin{array}{c}22.48 \pm \\
1.98\end{array}$ & $\begin{array}{c}22.14 \pm \\
1.36\end{array}$ & $\begin{array}{c}23.11 \pm \\
0.78\end{array}$ & NS \\
\hline $\begin{array}{l}\text { Duodenum weight } \\
\text { (\% }\end{array}$ & $\begin{array}{c}0.81^{\mathrm{b}} \pm \\
0.06\end{array}$ & $\begin{array}{c}1.15^{\mathrm{ab}} \pm \\
0.28\end{array}$ & $\begin{array}{c}1.70^{\mathrm{a}_{ \pm}} \\
0.33\end{array}$ & $\begin{array}{c}1.22^{\mathrm{ab}} \pm \\
0.35\end{array}$ & $\begin{array}{c}1.29^{\mathrm{ab}} \pm \\
0.34\end{array}$ & $\begin{array}{c}1.60^{\mathrm{ab}} \pm \\
0.21\end{array}$ & $\begin{array}{c}1.65^{\mathrm{a}_{ \pm}} \\
0.19\end{array}$ & $*$ \\
\hline $\begin{array}{l}\text { Duodenum length } \\
(\%\end{array}$ & $\begin{array}{c}6.87 \pm \\
0.27\end{array}$ & $\begin{array}{c}6.78 \pm \\
0.80\end{array}$ & $\begin{array}{c}7.57 \pm \\
0.87\end{array}$ & $\begin{array}{c}6.95 \pm \\
0.87\end{array}$ & $\begin{array}{c}6.23 \pm \\
0.45\end{array}$ & $\begin{array}{c}6.22 \pm \\
0.25\end{array}$ & $\begin{array}{c}7.25 \pm \\
0.63\end{array}$ & NS \\
\hline $\begin{array}{l}\text { Jejunum and ileum } \\
\text { weight }(\%)\end{array}$ & $\begin{array}{c}0.50^{\mathrm{b}} \pm \\
0.01\end{array}$ & $\begin{array}{c}1.13^{\mathrm{a}_{ \pm}} \\
0.12\end{array}$ & $\begin{array}{c}1.01^{\mathrm{ab}} \pm \\
0.22\end{array}$ & $\begin{array}{c}0.96^{\mathrm{ab}} \pm \\
0.20\end{array}$ & $\begin{array}{c}1.00^{\mathrm{ab}} \pm \\
0.06\end{array}$ & $\begin{array}{c}0.96^{\mathrm{ab}} \pm \\
0.19\end{array}$ & $\begin{array}{c}1.19^{\mathrm{a}} \pm \\
0.27\end{array}$ & $*$ \\
\hline $\begin{array}{l}\text { Jejunum and ileum } \\
\text { length }(\%)\end{array}$ & $\begin{array}{c}17.73 \pm \\
2.64\end{array}$ & $\begin{array}{c}15.95 \pm \\
0.08\end{array}$ & $\begin{array}{c}14.99 \pm \\
0.72\end{array}$ & $\begin{array}{c}14.93 \pm \\
2.66\end{array}$ & $\begin{array}{c}16.24 \pm \\
0.72\end{array}$ & $\begin{array}{c}15.92 \pm \\
1.57\end{array}$ & $\begin{array}{c}15.69 \pm \\
0.78\end{array}$ & NS \\
\hline Cecum weight (\%) & $\begin{array}{c}0.84^{\mathrm{b}} \pm \\
0.05\end{array}$ & $\begin{array}{c}0.86^{\mathrm{b}} \pm \\
0.09\end{array}$ & $\begin{array}{c}1.79^{\mathrm{a}} \pm \\
0.68\end{array}$ & $\begin{array}{c}0.94^{\mathrm{ab}_{ \pm}} \\
0.21\end{array}$ & $\begin{array}{c}0.85^{\mathrm{b}} \pm \\
0.29\end{array}$ & $\begin{array}{c}0.69^{\mathrm{b}} \pm \\
0.18\end{array}$ & $\begin{array}{c}1.55^{\mathrm{ab}} \pm \\
0.05\end{array}$ & $*$ \\
\hline Cecum length (\%) & $\begin{array}{c}10.51^{\mathrm{d}} \pm \\
0.96\end{array}$ & $\begin{array}{c}11.70^{\mathrm{bc}} \pm \\
0.85\end{array}$ & $\begin{array}{c}14.10^{\mathrm{a}} \pm \\
0.96\end{array}$ & $\begin{array}{c}10.86^{\mathrm{cd}} \pm \\
0.60\end{array}$ & $\begin{array}{c}12.98^{\mathrm{abc}} \pm \\
0.57\end{array}$ & $\begin{array}{c}10.90^{\mathrm{cd}} \pm \\
0.40\end{array}$ & $\begin{array}{c}13.59^{\mathrm{ab}} \pm \\
0.47\end{array}$ & $*$ \\
\hline $\begin{array}{l}\text { Abdominal fat } \\
\text { weight }(\%)\end{array}$ & $\begin{array}{c}1.02^{\mathrm{a}_{ \pm}} \\
0.01\end{array}$ & $\begin{array}{c}0.69^{\mathrm{b}} \pm \\
0.07\end{array}$ & $\begin{array}{c}0.70^{b_{ \pm}} \\
0.11\end{array}$ & $\begin{array}{c}0.69^{\mathrm{b}} \pm \\
0.10\end{array}$ & $\begin{array}{c}0.63^{\mathrm{b}} \pm \\
0.02\end{array}$ & $\begin{array}{c}0.64^{\mathrm{b}} \pm \\
0.06\end{array}$ & $\begin{array}{c}0.78^{\mathrm{b}} \pm \\
0.06\end{array}$ & $*$ \\
\hline Spleen weight (\%) & $\begin{array}{c}0.08^{\mathrm{a}} \\
\pm \\
0.003 \\
\end{array}$ & $\begin{array}{c}0.06^{\mathrm{b}} \\
\pm \\
0.007 \\
\end{array}$ & $\begin{array}{c}0.06^{\mathrm{b}} \\
\pm \\
0.006 \\
\end{array}$ & $\begin{array}{c}0.06^{\mathrm{b}} \\
\pm \\
0.006 \\
\end{array}$ & $\begin{array}{c}0.06^{\mathrm{b}} \\
\pm \\
0.004 \\
\end{array}$ & $\begin{array}{c}0.07^{\mathrm{ab}} \\
\pm \\
0.007 \\
\end{array}$ & $\begin{array}{c}0.06^{\mathrm{b}} \\
\pm \\
0.005 \\
\end{array}$ & $*$ \\
\hline $\begin{array}{l}\text { Bursa of fabricius } \\
\text { weight }(\%)\end{array}$ & $\begin{array}{c}0.40^{\mathrm{a}_{ \pm}} \\
0.05\end{array}$ & $\begin{array}{c}0.34^{\mathrm{ab}} \pm \\
0.03\end{array}$ & $\begin{array}{c}0.35^{\mathrm{ab}} \pm \\
0.01\end{array}$ & $\begin{array}{c}0.27^{\mathrm{bc}} \pm \\
0.03\end{array}$ & $\begin{array}{c}0.31^{b c} \pm \\
0.02\end{array}$ & $\begin{array}{c}0.25^{\mathrm{bc}} \pm \\
0.02\end{array}$ & $\begin{array}{c}0.22^{\mathrm{c}_{ \pm}} \\
0.01\end{array}$ & $*$ \\
\hline Bursa index & $\begin{array}{c}1.00^{\mathrm{a}} \pm \\
0.00\end{array}$ & $\begin{array}{c}0.81^{b_{ \pm}} \\
0.00\end{array}$ & $\begin{array}{c}0.84^{b_{1}} \\
0.03\end{array}$ & $\begin{array}{c}0.70^{b c_{ \pm}} \\
0.09\end{array}$ & $\begin{array}{c}0.77^{\mathrm{bc}} \pm \\
0.02\end{array}$ & $\begin{array}{c}0.62^{\mathrm{cd}_{ \pm}} \\
0.05\end{array}$ & $\begin{array}{c}0.54^{\mathrm{d}} \pm \\
0.04\end{array}$ & $*$ \\
\hline
\end{tabular}

${ }_{\text {abcd }}$ Means in the same row with no common superscript are different significantly ( $\left.\mathrm{P} \leq 0.05\right)$. NS: None significant, $\mathrm{T} 1$ (control), T2 and T3 (Tomato fruits powder at the levels of 17 and $34 \mathrm{~g}^{\mathrm{kg}} \mathrm{g}^{-1}$ in basal diet), T4 and T5 (Red bell pepper at the levels of 16.23 and $32.46 \mathrm{~g} . \mathrm{kg}^{-1}$ in basal diet) which was equivalent to 50 and $100 \mathrm{mg} \cdot \mathrm{kg}^{-1}$ lycopene respectively, T6 and T7 (lycopene powder at the levels of 50 and $100 \mathrm{mg} \cdot \mathrm{kg}^{-1}$ in basal diet) respectively. 
Our results are close to Rahmatnejad et al. (2011) except for carcass weight, thighs, liver and gizzard, who reported that supplementation of dried tomato pomace up to $8 \%$ broiler diets had comparable carcass weight, carcass yield, breast, thigh, abdominal fat, heart, liver and gizzard with those of control group.

The significant improvement of supplemented groups in the relative weight of small intestine and its parts may be due to lycopene role in improved palatability and increased digestibility, as a result of the increasing and secretion activity enzymes in the digestive system (Zhang et al., 2009). In addition to the improvement in the bodyweight of quails, it reflected positively on the relative weight of cecum, besides the presence of the fibre in cecum increasing the size of this organ compared to the other organs (Nikolakakis et al., 2004), because microbial digestion of cellulosic substances occur

\section{Conflicts of interest}

The authors declare that they have no conflict of interests.

\section{Ethical approval}

All applicable institutional, national and international guidelines for the care and use of animals were followed.

\section{Conclusion}

It could be concluded that the supplementation of fruit powders of tomato $\left(17 \mathrm{~g} \cdot \mathrm{kg}^{-1}\right)$ and red bell pepper $\left(16.23 \mathrm{~g} \cdot \mathrm{kg}^{-1}\right)$ as a natural source of pure lycopene (50 mg. $\left.\mathrm{kg}^{-1}\right)$, led to an improvement in the productive performance, production index, economic efficiency index, carcass traits and some gut measurements of Japanese quail.

\section{Acknowledgements}

The authors thank the staff of Department of Animal Production and Quail Farm in Agriculture College, University of Basrah, and its Personnel of their assistance with this study.

\section{Rabia J. Abbas: https://orcid.org/0000-0003- 1330-9894}

\section{References}

Abdullah, M.A., Al-Dajah, S., Abu Murad, A., El-Salem, A. M., \& Khafajah, A. M. (2019). Extraction, purification, and characterization of lycopene from Jordanian vine tomato cultivar, and study of its potential natural antioxidant effect on Samen Baladi. Current Research in Nutrition and Food Science, 7, 532-546. http://dx.doi.org/10.12944/CRNFSJ.7.2.22

Al-Fayadh, H. A. A., \& Naji, S. A. H. (1989). Poultry Products Technology. Ministry of Higher Education Press. University of Baghdad: 626pp. (In Arabic).

Al-Fayadh, H. A. A., Naji, S. A. H., \& Al-Hajo, N. N. (2011). Poultry Meat Technology. $2^{\text {nd }}$ part. Higher Education Press, University of Baghdad, 292pp. (In Arabic).

Ali, N. A. L., \& Al Massad, M. (2015). Effect of adding Lycopene to the ration on productive traits of broiler ROSS 308. International Journal of Current Research, $7 . \quad 23011-23014$. http://www.journalcra.com.

Al-Janaby, Y. A. M. (2015). Effect of dietary supplementation with different levels of lycopene on productive, physiological and reproductive performance of local geese. Ph. D. Thesis. Fac. Agric., Univ. Baghdad, 178pp. (In Arabic).

Al-Shammary, K. E. A. S. (2017). Efficiency of dietary zinc and lycopene to counteract oxidative stress of Japanese quail. Iraqi Poultry Sciences Journal, 11, 44-58. https://iasj.net/iasj?func=fulltext\&aId=157214

A.O.A.C. (2016). Official Methods of Analysis of AOAC International. George W., \& Latimer, Jr. (Eds.), (20 ${ }^{\text {th }}$ ed.). Rockville, Maryland 20850-3250, 3172pp.

Arain, M. A., Mei, Z., Hassan, F. U., Saeed, M. Alagawany, M., Shar, A. H., \& Rajput, I. R. (2018). 


\section{Al-Jrrah \& Abbas / Basrah J. Agric. Sci., 33(2): 52-66, 2020}

Lycopene: a natural antioxidant for prevention of heat-induced oxidative stress in poultry. World's Poultry Science Journal, 74, 112.https://doi.org/10.1017/S0043933917001040

Asadollahi, S., Karimi, N., \& Mansuri, A. (2014). Using of dried tomato pomace in broiler's diet and its effect on chemical components of obtained meat. In Int. Conf. Chem., Agric., Biol. Sci. In International Conference on Chemical, Agricultural, and Biological Sciences ICCABS'2014) Oct. 9-10, 2014, Antalya (Turkey).

Aziz, H. H., Kadim, M. M. \& Desher, M. A. (2019). Effect of organic compost on chemical parameters for two varieties of tomato plant (Solanum esculentium L.). Basrah Journal of Agricultural Sciences, 32(Spec. Issue 262-271. https://doi.org/10.37077/25200860.2019.274

Dougnon, T. J., Kiki, P., Dougnon, T. V., \& Youssao I. (2014). Evaluation of Capsicum frutescens powder effects on the growth performances, biochemical and hematological parameters in Hubbard broiler. Journal of Applied Pharmaceutical Science, 4, 038-043. https://doi.org/10.7324/JAPS.2014.40107

El-Taz, S. M. A. (2014). Response of broiler chicken to diets containing different mixture powder levels of red pepper and black pepper as natural feed additive. Animal and Veterinary Sciences, 2, 81-86. https://doi.org/10.11648/j.avs.20140203.15

Estruch, R., Ros, E., Salas-Salvadó, J., Covas, M. -I., Corella, D., Arós, F., \& MartínezGonzález, M. A. (2013). Primary prevention of cardiovascular disease with a Mediterranean diet. New England Journal of Medicine, 368, 1279-1290.https://doi.org/ 10.1056/NEJMoa1200303.

Flint, J. F., \& Garner, M. R. (2009). Feeding beneficial bacteria: A natural solution for increasing efficiency and decreasing pathogens in animal agriculture. Journal of Applied Poultry Research, 18, 367-378. https://doi.org/10.3382/japr.2008-00133.

Jang, I. S., \& Moon, Y. S. (2015). Effects of lycopene on the expression of lipid metabolism, glucose transport and pro-inflammatory related genes in chickens. Korean Journal of Poultry Science, 42, 231-238. https://doi.org/10.5536/KJPS.2015.42.3.231
Khan, R. U., Zia-Ur-Rahman, Javed, I., \& Muhammad, F. (2014). Serum antioxidants and trace minerals as influenced by vitamins, probiotics and proteins in broiler breeders. Journal of Applied Animal Research, 42 , 249-255. https://doi.org/10.1080/09712119.2013.822815

Lee, K. W., Choo, W. D., Kang, C. W., \& An, B. K. (2016). Effect of lycopene on the copper-induced oxidation of low-density lipoprotein in broiler chickens. Springer Plus, 5, 389. https://doi.org/10.1186/s40064-016-2035-6

Leke, J. R., Mandey, J.S., Ratulangi, F., \& Najoan, M. (2018). Effect of tomato (Solanum lycopersicum L.) protein on carcass and meat quality of Kampong chicken. Journal of Indonesian Tropical Animal Agriculture, $\quad 43, \quad 35-42$. https://doi.org/10.14710/jitaa.43.1.35-42.

Lodhi, G. N., Singh, D., \& Ichhponani, J. S. (1976). Variation in nutrient content of feeding stuffs rich in protein and reassessment of the chemical method for metabolizable energy estimation for poultry. The Journal of Agricultural Science, 86, 293-303. https://doi.org/10.1017/S0021859600054757

Lucio, B., \& Hitchner, S. B. (1979). Infection bursal disease emulsified vaccine: Effect upon neutralizingantibody levels in the dam and subsequent protection of the progeny. Avian Diseases, 23, 466-478. https://doi.org/10.2307/1589577

Marković, K., Mirjana, H., \& Nada, V. (2006). Lycopene content of tomato products and their contribution to the lycopene intake of Croatians. Nutrition Research, 26(11): 556-560. https://doi.org/10.1016/j.nutres.2006.09.010

Marzoni, M., Chiarini, R., Castilo, A., Romboli, I., De Marco, M., \& Schiavone, A. (2014). Effects of dietary natural antioxidant supplementation on broiler chicken and Muscovy duck meat quality. Animal Science Paper and Reports, 32, 359-368.

Mendelova, A., Fikselova, M., \& Mendell, L. M. (2013). Carotenoids and lycopene content in fresh and dried tomato fruits and tomato juice. Acta Universitatis Agriculturae et Silviculturae Mendelianae Brunensis, 61 , 1329-1337. https://doi.org/10.11118/actaun201361051329 
Al-Jrrah \& Abbas / Basrah J. Agric. Sci., 33(2): 52-66, 2020

Mercy, E.R., \& David, U. (2018). Potential health benefits of conventional nutrients and phytochemicals of Capsicum peppers. Pharmacy \& Pharmacology International Journal, 6, 62-69.https://doi.org/ 10.15406/ppij.2018.06.00157

Mezbani, A., Kavan, B. P., Kiani, A., \& Masouri B. (2019). Effect of dietary lycopene supplementation on growth performance, blood parameters and antioxidant enzymes status in broiler chickens. Livestock Research for Rural Development, 31(1). http://www.lrrd.org/lrrd31/1/bahma31012.html

Mozaffarian, D. (2016). Dietary and policy priorities for cardiovascular disease, diabetes, and obesity. Circulation, 133, 187-225. https://doi.org/10.1161/ CIRCULATIONAHA.115.018585

Naji, S. A. H. (2006). Commercial Broiler Production Manual. Iraqi Poultry Science Association (IPSA). Brochure No. 12, 106pp. (In Arabic).

Nikolakakis, I., Banakis, D., Florou-Paneri, P., Dotas, V., Giannenas, I., \& Botsoglou, N. (2004). Effect of dried tomato pulp on performance and carcass characteristics of growing quails. Archiv fur Geflugelkunde, 68, 34-38.

NRC, National Research Council. (1994). Nutrient Requirements of Poultry. $9^{\text {th }}$ ed. National Academy of Science. Washington, D.C.: 176pp. http://www.nap.edu/catalog/2114.html

North, O. M. (1984). Commercial Chicken Production Annual . $3^{\text {rd }}$ edn. AV1 Publ. Company Inc. West port, Connecticut: 710pp.

Ognik, K., Cholewinska E., Sembratowicz I.; Grela, E., \& Czech A. (2016). The potential of using plant antioxidants to stimulate antioxidant mechanisms in poultry. World's Poultry Science Journal, 72, 291298.https://doi.org/10.1017/S0043933915002779

Omri, B., Alloui, N., Durazzo, A., Lucarini, M., Aiello, A., Romano, R.; Santini, A., \& Abdouli, H. (2019). Egg yolk antioxidants profiles: Effect of diet supplementation with linseeds and tomato-red pepper mixture before and after Storage. Foods, 8, 320. https://doi.org/10.3390/foods 8080320

Palozza, P., Catalano, A., Simone, R. E., Mele, M. C., \& Cittadini A. (2012). Effect of lycopene and tomato products on cholesterol metabolism. Annals of
Nutrition and Metabolism, 61, 126-134. https://doi.org/10.1159/000342077

Rahmatnejad, E., Pour, M. B., Mamuel, M., Mirzadeh, K., \& Perai, A. H. (2011). The effects of dried tomato pomace and a multiple enzyme mixture supplementation (Rovabio Excel TM) on performance and carcass quality of broiler chickens. African Journal of Biotechnology, 10, 9207-9212. https://doi.org/10.5897/AJB10.2325

Rao, A. V., \& Agarwal, S. (1999). Role of lycopene as antioxidant carotenoid in the prevention of chronic diseases: A review. Nutrition Research, 19, 305-323. https://doi.org/10.1016/S0271-5317(98)00193-6

Rao, A. V., \& Rao, L. G. (2007). Carotenoids and human health. Pharmacological Research,55, 207-216. https://doi.org/10.1016/j.phrs.2007.01.012

Sahin, K., Onderci, M., Sahin, N., Gursu, M. F., Khachik, F., \& Kucuk, O. (2006). Effects of lycopene supplementation on antioxidant status, oxidative stress, performance and carcass characteristics in heat-stressed Japanese quail. Journal of Thermal Biology, 31, 307-312. https://doi.org/ 10.1016/j.jtherbio.2005.12.006.

Sahin, N., Orhan, C., Tuzcu, M., Sahin, K., \& Kucuk, O. (2008). The effects of tomato powder supplementation on performance and lipid peroxidation in quail. Poultry Science, 87, 276-283. https://doi.org/10.3382/ps.2007-00207

Sahin, K., Orhan, C., Tuzcu, M., Sahin, N., Hayirli, A., Bilgili, S., \& Kucuk, O. (2016). Lycopene activates antioxidant enzymes and nuclear transcription factor systems in heat-stressed broilers. Poultry Science, 95, 1088-1095. http://dx.doi.org/10.3382/ps/pew012

Selim, N. A., Youssef, S. F., Abdel-Salam, A. F., \& Nada, S. A. (2013). Evaluation of some natural antioxidant sources in broiler diets: 1-Effect on growth, physiological, microbiological and immunological performance of broiler chicks. International Journal of Poultry Science, 12, 561571. https://doi.org/ 10.3923/ijps.2013.561.571

Ševčíková, S.; Skřivan, M. \& Dlouhá, G. (2008). The effect of lycopene supplementation on lipid profile and meat quality of broiler chickens. Czech Journal of Animal Science, 53, 431-440. https://doi.org/10.17221/350-CJAS. 
Al-Jrrah \& Abbas / Basrah J. Agric. Sci., 33(2): 52-66, 2020

Shehata, S.F., Kamel, E.R., Abo-Salem, M.E.S. \& Atallah, S.T. (2018). Effect of some dietary supplementation on economic efficiency of growing Japanese Quails. Benha Veterinary Medical Journal (BVMJ), 34, 219-231. http://www.bvmj.bu.edu.eg

SPSS. (2012). SPSS User's Guide Statistics. Version 19. Copyright IBM, SPSS Inc.

Sun, B., Chen, C., Wang, W., Ma, J., Xie, Q., Gao, Y., Chen, F., Zhang, X., \& Bi, Y. (2015). Effects of lycopene supplementation in both maternal and offspring diets on growth performance, antioxidant capacity and biochemical parameters in chicks. Journal of Animal Physiology and Animal Nutrition, 99, 42-49. https://doi.org/10.1111/jpn.12196

Surendar, J., Shere, D. M., \& Shere, P. D. (2018). Effect of drying on quality characteristics of dried tomato powder. Journal of Pharmacognosy and Phytochemistry, 2690-2694. https://www.phytojournal.com

Tawfeek S.S., Hassanink, K.M.A., \& Youssef I.M.I. (2014). The effect of dietary supplementation of some antioxidants on performance, oxidative stress and blood parameters in broilers under natural summer conditions. Journal World's Poultry Research, 4, 1019.

Tundis, R., Loizzo, M.R., Menichini, F., Bonesi, M., Confortif, F., Statti, G., De Luca, D., De Cindio, B., \& Menichini, F. (2011). Comparative study on the chemical composition, antioxidant properties and hypoglycaemic activities of two Capsicum annuum L. cultivars (Acuminatum small and Cerasiferum). Plant Foods for Human Nutrition, 66: 261-269. https://doi.org/10.1007/s11130-011-0248-y
Vitale, A. A., Bernatene, E. A., \& Pomilio, A.B. (2010). Carotenoids in chemoprevention: Lycopene. Acta bioquímica clínica latinoamericana, 44, 195-238. (Abs.)

Wallace, R. J., Oleszek, W., Franz, C., Hahn, I., Baser, K. H. C., Mathe, A., \& Teichmann, K. (2010). Dietary plant bioactives for poultry health and productivity. British Poultry Science, 51, 461-487. https://doi.org/10.1080/00071668.2010.506908

Wang, X. D. (2012). Lycopene metabolism and its biological significance. The American journal of Clinical Nutrition, 96, 1214S-1222S. https://doi.org/10.3945/ajcn.111.032359

Yahia E. M. (2009). The contribution of fruit and vegetable consumption to human health. 3-51 In de la Rosa, L.A.; Alvarez-Parrilla, E. \& Gustavo A. González-Aguilar, G.A. (Eds.). Fruit and Vegetable Phytochemicals: Chemistry, Nutritional Value, and Stability. Oxford, Wiley-Blackwell. 367pp. DOI:10. 1002/9781119158042

Zhang, G. F., Yang, Z. B., Wang, Y., Yang, W. R., Jiang, S. Z., \& Gai, G. S. (2009). Effects of ginger root (Zingiber officinale) processed to different particle sizes on growth performance, antioxidant status, and serum metabolites of broiler chickens. Poultry science, $\quad 88, \quad 2159-2166$. https://doi.org/10.3382/ps.2009-00165.

Zhao, X., Yang, Z. B., Yang, W. R. Wang, Y., Jiang, S. Z., \& Zhang, G. G. (2011). Effects of ginger root (Zingiber officinale) on laying performance and antioxidant status of laying hens and on dietary oxidation stability. Poultry Science, 90, 1720-1727. https://doi.org/10.3382/ps.2010-01280. 
Al-Jrrah \& Abbas / Basrah J. Agric. Sci., 33(2): 52-66, 2020

تأثير المصادر الطبيعية والصناعية للايكوبين في الأداء الإنتاجي وصفات الأبيحة ووزن الاحشاء النسبي في

\section{Coturnx japonica السمان الياباني}

\section{عيسى عبد الله ثامر الجراح1 و ربيعة جدوع عباس2

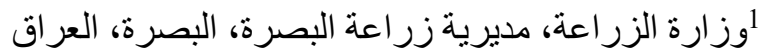

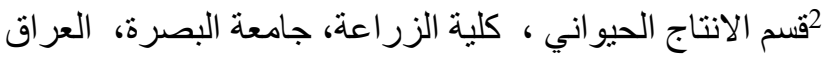

المستخلص: هدفت الدراسة لمعرفة تأثير المصادر الطبيعية والصناعية للليكوبين في الأداء الانتاجي وصفات الذبيحة ومورفولوجيا الأعضاء في السمان الياباني (Coturnx japonica). تم توزيع 420 فرخاً غير مجنس بعمر يوم واحد من طيور السمان الياباني عشوائيا على سبع معاملات تجريبية وبواقع ثلاث مكررات للمعاملة الواحدة و20 فرخا لكل مكرر. تناولت المعاملة الاولى العليقة الاساسية واعتبرت معاملة سيطرة. وأضيف مسحوق ثمار الطماطم الى العليقة الاساسية بالمستويين 17 و 34 (غم.كغغ -1) بالمعاملة الثانية والثالثة لتجهير 50 و100 (ملغم.كغم-1) ليكوبين على التوالي, ومسحوق الفلفل البارد الاحمر الى العليقة الاساسية بالمستويين

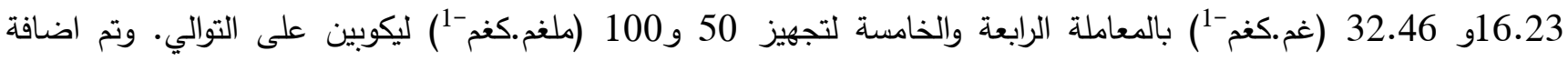
مسحوق اليكوبين النقي (الصناعي) بالمستويين 50 و100 (ملغم.كغم-1) الى العليقة الاساسية في المعاملتين السادسة والسابعة على لئ التوالي. أشارت النتائج حصول تحسن معنوي (Ps0.05) في وزن الجسم النهائي والزيادة الوزنية التراكمية مقارنة بمعاملة السيطرة و T3 وتحسن معنوي في كفاءة التحويل الغذائي مقارنة بالسيطرة و T3 و T7. وتحسنت قيم الدليل الانتاجي والكفاءة الاقتصادية

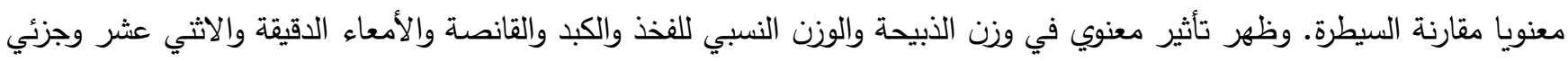

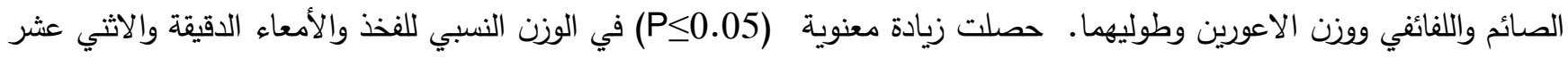
ووزن الاعورين وطوليهما في T3، وفي وزن جزئي الصائم واللفائفي في T7، وفي وزن الذبيحة والقانصة في المعاملة الرابعة وفي وزن الكبد في T5 مقارنة مع السيطرة. في حين حصل انخفاض معنوي (p<0.05) في الوزن النسبي للطحال وطبقة دهن البطن وفي دليل غدة فابريشيا لجميع معاملات الاضافة مقارنة بالسيطرة. نستتج من الدراسة الحالية امكانية استخدام المصادر الطبيعية لليكوبين (50)

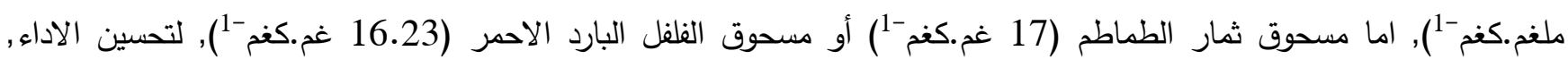
الدليل الانتاجي, الكفاءة الاقتصادية, صفات الذبيحة, الوزن النسبي للأمعاء الدقيقة، الاثني عشر وجزئي الصائم واللفائفي لطيور السمان. 